\title{
Influence of Water-to-Cement Ratio on the Compressive Strength of Cement- Biochar-Spent Ion Exchange Resins Matrix
}

\author{
(Pengaruh Nisbah Air-Simen terhadap Kekuatan Mampatan Matriks Simen-Bioarang-Resin Pertukaran Ion Terpakai)
}

\author{
ZALINA LAILI*, MuHAMAD SAMUdi YASIR \& MOHD ABDUl WAHAB YusOF
}

\begin{abstract}
The influence of water-to-cement ratio $(w / c)$ on the compressive strength of cement-biochar-spent resins matrix was investigated. Spent resins waste from nuclear reactor operation was solidified using cement with w/c ranging from 0.35 to 0.90 by weight. In this study, biochar was used as a cement admixture. Some properties of spent resins and biochar were determined prior to the formulation study. Compressive strength of harden cement-biochar-spent resins matrix was determined at 28 days. The compressive strength of cement-biochar-spent resins matrix was found to depend on the $w / c$ and the amount of spent resins added to the formulation. The immersion test of cement-biochar-spent resins matrix showed no significant effects of cracking and swelling. The compressive strength of the cement-biochar-spent resins matrix increased after two weeks in water immersion test.
\end{abstract}

Keyword: Compressive strength; radioactive waste; solidification; spent ion exchange resins; water-to-cement ratio

\section{ABSTRAK}

Pengaruh nisbah air-simen $(w / c)$ terhadap kekuatan mampatan matriks simen-bioarang-resin pertukaran ion terpakai telah dikaji. Sisa resin terpakai daripada operasi reaktor nuklear telah dipejalkan dengan menggunakan simen dengan w/c daripada 0.35 hingga 0.90. Dalam kajian ini, bioarang digunakan sebagai bahan tambah kepada simen. Beberapa ciri resin terpakai dan bioarang telah ditentukan sebelum kajian formulasi. Kekuatan mampatan matriks simen-bioarangresin terpakai yang mengeras ditentukan pada umur 28 hari. Kekuatan mampatan simen-bioarang-resin terpakai didapati bergantung kepada nisbah simen-air dan jumlah resin terpakai yang ditambah kepada formulasi. Ujian rendaman air bagi matriks simen-bioarang-resin terpakai menunjukkan tiada kesan ketara keretakan dan pengembangan berlaku. Kekuatan mampatan matriks simen-bioarang-resin terpakai didapati meningkat selepas dua minggu ujian rendaman air.

Kata kunci: Kekuatan mampatan; nisbah simen-air; pemejalan; resin pertukaran ion terpakai; sisa radioaktif

\section{INTRODUCTION}

Large amounts of spent ion exchange resins (spent resins) are constantly generated from water purification in a nuclear reactor. These spent resins are classified as low level or intermediate-level radioactive waste (IAEA 1985). Spent resins often contain high concentrations of radioactivity such as Cs-137 and Co-60, with half-lives of 30 and 5.3 years, respectively (Travcar et al. 2007). Generally, one of the most common treatment methods in the nuclear industry for treating spent resins is using cement solidification. This method typically involves the mixing of spent resins with cement to reduce the radionuclides mobility by both physical and chemical mechanisms. Most of the cemented radioactive wastes are stored and disposed at near surface (Ojovon et al. 2011). Hence, there are some critical properties that must be considered to ensure the cemented waste form durability in disposal facility (IAEA 1993). Cemented waste form properties of the highest interest are mechanical and thermal properties, radiation stability and leach resistance (IAEA 1985). The knowledge of mechanical properties is essential to guarantee that the product will have adequate strength to allow normal handling, transport and storage (Lee \& Wilding 1989). The mechanical strength of cemented waste form can be determined by performing compression strength test on a standard cylindrical or cube specimens. This compressive strength indicates the compressive loading required to fracture the cemented waste form (IAEA 1985). One of the most important factors affecting mechanical strength of cemented waste form is water-to-cement ratio $(w / c)$. It is also the dominant factor which affects cement hydration since w/c directly controls the volume of water available for hydration of each unit cement particle, as well as the spacing between the cement particles (Hu et al. 2014). The optimum amount of water is required to produce a homogenous mixture in a reasonable time and the final waste form has good mechanical strength. If too little water, the mixture will be stiff, difficult to mix and compact. Nevertheless, too much water will result in a fluid mix and produce a weak and permeable product (Glasser 2011).

The spent resins from a nuclear reactor are a problematic type of waste (IAEA 2002) as it is the most difficult type of radioactive waste to be cemented (Junfeng $\&$ Jianlong 2006). The spent resins tend to swell after 
contact with water especially when the resin content is higher (IAEA 1985). The swelling can result in micro cracks in the cement and a change in the overall of the cement structure (IAEA 2002). Therefore, the strength of matrix that relates to the resins loading and the water-to-cement ratio is of most concern. In this study, biochar was selected as a cement admixture for spent resins solidification. Biochar has a relatively structured carbon matrix with high degree of porosity and an extensive surface area and it may act as a surface sorbent when activated (Chen et al. 2011). This study was performed to investigate the influence of w/c on the compressive strength of cement-biochar-spent resins matrix. The characterization studies of biochar and spent resins were conducted prior to the formulation studies. The effect of immersion test on the compressive strength was then performed on the prepared specimens.

\section{MATERIALS AND METHODS}

\section{BIOCHAR PREPARATION AND CHARACTERISATION}

Biochar used in this study was obtained from Universiti Putra Malaysia, Serdang Selangor. The biochar was produced from the pyrolysis of oil palm empty fruit bunch $(\mathrm{EFB})$ at medium temperature $\left(250-450^{\circ} \mathrm{C}\right)$. Then, it was ground and sieved by USA Standard Sieve No. 18 (corresponding to $1 \mathrm{~mm}$ ) before being used for the formulation studies. Some properties of the biochar were investigated. $\mathrm{pH}$ of biochar was determined by dissolving $1.0 \mathrm{~g}$ of biochar in $100 \mathrm{~mL}$ of distilled water and then shaking for $24 \mathrm{~h}$ and $\mathrm{pH}$ then determined using a $\mathrm{pH}$ meter (Trans Instruments Model BP 3001). Elemental C, H, N and $\mathrm{S}$ were determined using CHNS Analyser (Model CHNS932, USA). Proximate analysis was conducted to measure the moisture content (ASTM E949), volatile matter (ASTM E897-88) and ash content (ASTM E830-87). Radionuclides content in biochar was determined using a Canberra n-type high purity germanium (HPGe) gamma spectrometer system with $30 \%$ relative efficiency and a resolution of $1.9 \mathrm{keV}$ at $1332.5 \mathrm{keV}$ of Co-60.The surface morphology of biochar was examined by a scanning electron microscope (SEM) (model FEI 400). The analysis on the functional groups of biochar was performed using Fourier transform infrared spectrophotometer (FTIR) (model Spectrum 2000/L183, USA) in the range of 500 to $4000 \mathrm{~cm}^{-1}$. X-ray diffraction (XRD) analysis was carried out to identify any changes in the crystallographic structure in biochar sample using a PANalytical diffractometer, model X PERT PRO MPD (PW 3040/60).

\section{SPENT RESINS COLLECTION AND CHARACTERISATION}

Spent resins of the year 2010 were obtained from Waste Development Technology Centre at Malaysian Nuclear Agency, Bangi Selangor. The spent resins samples were collected using a scoop and transferred directly into clean plastic containers before being brought to the laboratory for characterisation. The spent resins were synthetic organic ion exchange resins (i.e. Amberlite resin), which are strongly acidic gelular polystyrene cation exchange resins. Some important characteristics of spent resins were determined which include the water content, $\mathrm{pH}$, conductivity and radionuclides contents. Determination of water content were conducted by drying the spent resins to a constant mass in an oven at $105^{\circ} \mathrm{C}$ and then its water content were calculated. The $\mathrm{pH}$ and conductivity of spent resins were measured by dissolving $30 \mathrm{~g}$ of spent resins in $100 \mathrm{~mL}$ of distilled water. The mixture then was stirred for about $24 \mathrm{~h}$ and the $\mathrm{pH}$ and conductivity were determined using a $\mathrm{pH}$ meter (Trans Instruments Model BP 3001) and a conductivity meter (Trans Instrument model HC 3010) respectively. Analysis of radionuclides content were measured using a Canberra n-type high purity germanium (HPGe) gamma spectrometer system with $30 \%$ relative efficiency and a resolution of $1.9 \mathrm{keV}$ at 1332.5 $\mathrm{keV}$ of $\mathrm{Co}-60$.

\section{SPECIMEN PREPARATION}

Cement used for solidification of spent resins was Portland cement (Lafarge Phoenix Brand). Different weights (wt) of biochar were mixed with Portland cement from 1\% - 16\% (wt/wt), after which the spent resins were added to the cement paste. The ratio of spent resins-to-biochar was 1:1 by wt. For example, $20 \mathrm{~g}$ of spent resins was added together with $20 \mathrm{~g}$ of biochar in cement paste. Water-to-cement ratio is the weight ratio of water and cement and it is an important factor in influencing mechanical strength (Sun et al. 2011). The water-to-cement (w/c) ratios conducted in this study were $0.35-0.90$. All mixtures were thoroughly mixed using laboratory electric cement mixer for about $10 \mathrm{~min}$ at room temperature $\left(26 \pm 1^{\circ} \mathrm{C}\right)$. The mixtures were cast into $10 \mathrm{~cm}$ diameter cylindrical moulds with a height of $10 \mathrm{~cm}$ and then allowed to set and harden at room temperature. Three identical samples were made for each formulation. After $24 \mathrm{~h}$, the specimens were demoulded, then sealed in plastic bags and cured in water for 28 days. For the purposes of this investigation each formulation were evaluated to determine acceptable solidification formulation based on three criteria i.e. workability, monolithic solid and free standing water.

\section{MECHANICAL STRENGTH TEST}

Mechanical integrity was determined by measuring compressive strength of the cement-spent resins matrices. Compressive strength of 28 days cured cement-biocharspent resins matrices were measured following the test protocol specified by ASTM C-39/C39M-09a method. The compressive strength was measured using ENERPAC (Model P-84/USA) compression tester with a maximum load of $1000 \mathrm{psi} / 700$ bar. Three measurements were performed for each data point and the average plus/minus standard deviation was determined. The criterion of mechanical strength for cement waste form is $>3.45 \mathrm{Mpa}$ (500 psi) as recommended by the US Nuclear Regulatory Commission (NRC) Standard (NRC-US 1991). 


\section{WATER IMMERSION TEST}

To determine the effect of water immersion on the mechanical strength, specimens with different formulations were subjected to a two weeks water immersion test. Specimens were fully immersed in distilled water and ground water. The groundwater was collected from wells at Sg. Chongkak, Hulu Langat, Selangor. The specimens were also visually inspected for evidence of cracking and swelling after immersion test. If there was no significant immersion effects, the specimen were tested for mechanical strength.

\section{RESULTS AND DISCUSSION}

\section{CHARACTERISATION OF BIOCHAR}

The physico-chemical characteristics of biochar used in this study are shown in Table 1. Biochar is shown to have alkaline $\mathrm{pH}$. Generally, the $\mathrm{pH}$ is very important in the context of radioactive waste immobilization (Atkins $\&$ Glasser 1992). Moreover, the alkaline conditions are required to maintain the low solubility of many radionudides during solidification process. The fixed carbon and volatile matter content of biochar were $40.22 \%$ and $22.1 \%$, respectively. The result from elemental analysis showed that biochar was carbon rich and had carbon $(\mathrm{C})$ content around $45.3 \%$. This carbon content might affect the colour of cemented spent resin matrices (Figure 1). Hence, the higher the percentage of biochar used, the darker the colour of cement-spent resin matrix. The hydrogen/carbon $(\mathrm{H} / \mathrm{C})$ ratio of 0.05 , which indicates the degree of carbonization (Chen et al. 2011). The high H/C ratio suggests that biochar still contain a certain amounts original plant organic residue such as cellulose (Chun et al. 2004). The results of gamma spectrometric analysis showed that only natural radionuclides (Ra-226, Ra-228 and K-40) were detected in the biochar. The SEM images showed that surface morphology of biochar was irregular and had a macroporosity structure (Figure 2) which may be beneficial for radionuclides adsorption. The major bands of FTIR spectra for biochar are shown in Figure 3. The FTIR spectra of biochar revealed a broad band at $3333 \mathrm{~cm}^{-1}$ arising from stretching vibration of hydroxyl groups and indicated significant hydrogen-bonding interaction. The absorptions bands at 2907 and $2851 \mathrm{~cm}^{-1}$ corresponding to aliphatic $\mathrm{C}-\mathrm{H}$ stretching vibrations of cellulose and $\mathrm{C}-\mathrm{OH}$ stretching vibration in secondary alcohols group. Other absorption bands were 1985 and $1574 \mathrm{~cm}^{-1}(\mathrm{C}=\mathrm{O}$ stretching of aromatics rings), $1020 \mathrm{~cm}^{-1}$ (C-O stretching) and 709

TABLE 1. Physico-chemical characteristics of biochar

\begin{tabular}{lr}
\hline \multicolumn{1}{c}{ Characteristics } & \multicolumn{1}{c}{ Biochar } \\
\hline $\mathrm{pH}$ & 9.25 \\
\hline Proximate analysis (\%) & \\
Moisture Content & $6.41 \pm 0.37$ \\
Ash Content $(\%)$ & $31.27 \pm 1.78$ \\
Fixed Carbon (\%) & $40.22 \pm 1.14$ \\
Volatile Matter (\%) & $22.10 \pm 1.00$ \\
\hline Elemental Analysis (wt \%) \\
$\mathrm{C}(\%)$ & $45.3 \pm 11.62$ \\
$\mathrm{H}(\%)$ & $2.48 \pm 0.22$ \\
$\mathrm{~N}(\%)$ & $3.01 \pm 1.32$ \\
$\mathrm{~S}(\%)$ & $<0.05$ \\
\hline Radionuclides Contents (Bq/g) & \\
Ra-226 & $0.023 \pm 0.002$ \\
Ra-228 & $0.0087 \pm 0.0045$ \\
$\mathrm{~K}-40$ & $2.27 \pm 0.06$ \\
\hline
\end{tabular}
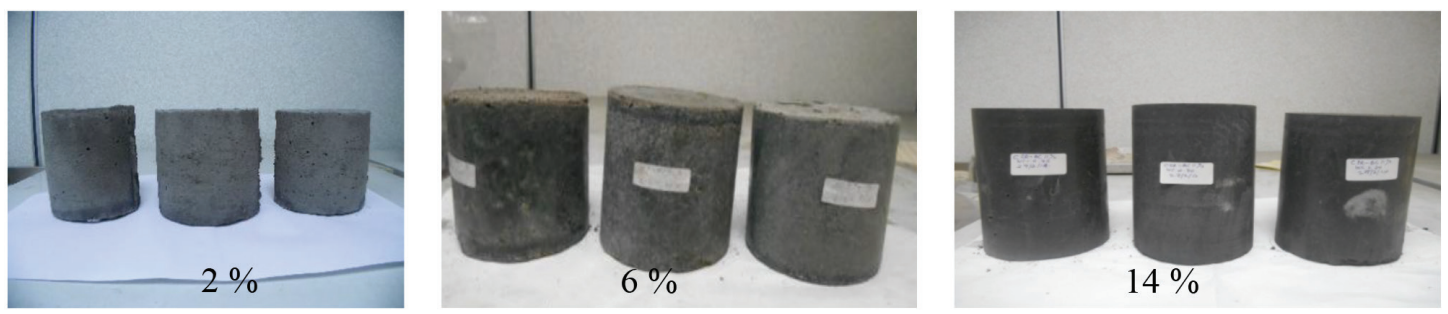

FIGURE 1. Cement-spent resins matrices with different amounts of biochar
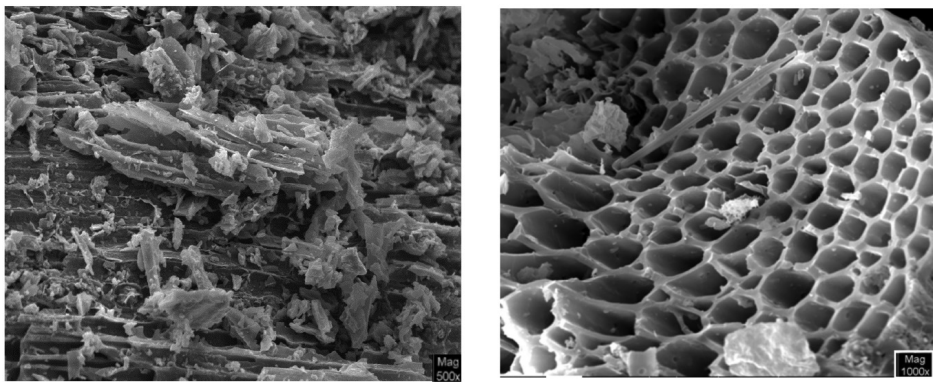

FIGURE 2. SEM micrographs of biochar 


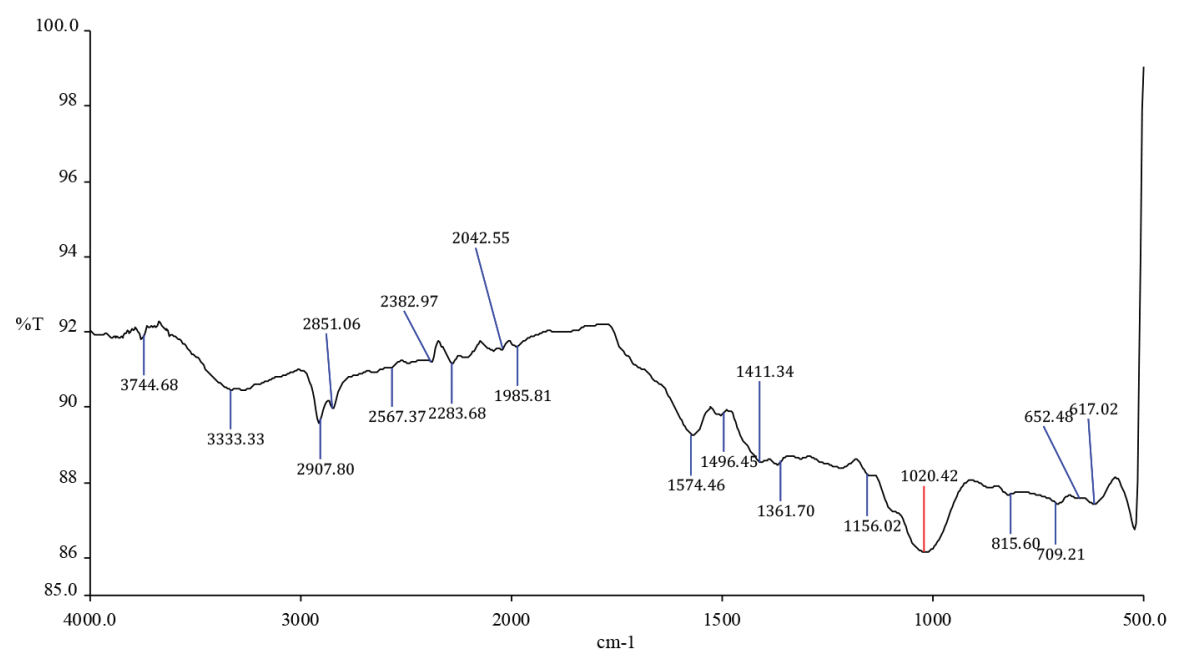

FIGURE 3. FTIR spectrum of biochar

$\mathrm{cm}^{-1}$ (C-H stretching). These functional groups can interact with cation to form surface complexes on biochars (Tong et al. 2011). The XRD spectra of biochar had several peaks (Figure 4), indicating the presence of mineral crystals.

\section{CHARACTERISATION OF SPENT RESINS}

The properties of spent resins are shown in Table 2. The results show that the spent resins were acidic in nature. The spent resins used in this study were removed from reactor facility in Malaysian Nuclear Agency in the year 2010. Thus, after 3 years the water content in the spent resins was about $38.33 \%$ and this indicates that dewatering for spent resins is unnecessary before solidification process. In general, the volumes of spent resins need to be reduced prior to solidification process (IAEA 1985). This is because too much water $(>50 \%)$ in the spent resins can affect the final product strength. The conductivity of spent resins leachate was $24.6 \mu \mathrm{S}$ which indicates that a small amount of ions were released into the solutions. The radionuclides detected in spent resins were activation products (Mn-54, Co-60, Zn65 and Eu-152) and small activity concentrations of fission products (Cs-134 and Cs-137). The highest concentration was found in Co-60 (151.64 $\pm 2.08 \mathrm{~Bq} / \mathrm{g})$.

\section{COMPRESSIVE STRENGTH}

A certain minimum mechanical strength is needed for solidified waste to ensure the waste is stable during handling, storage, transportation and final disposal (IAEA

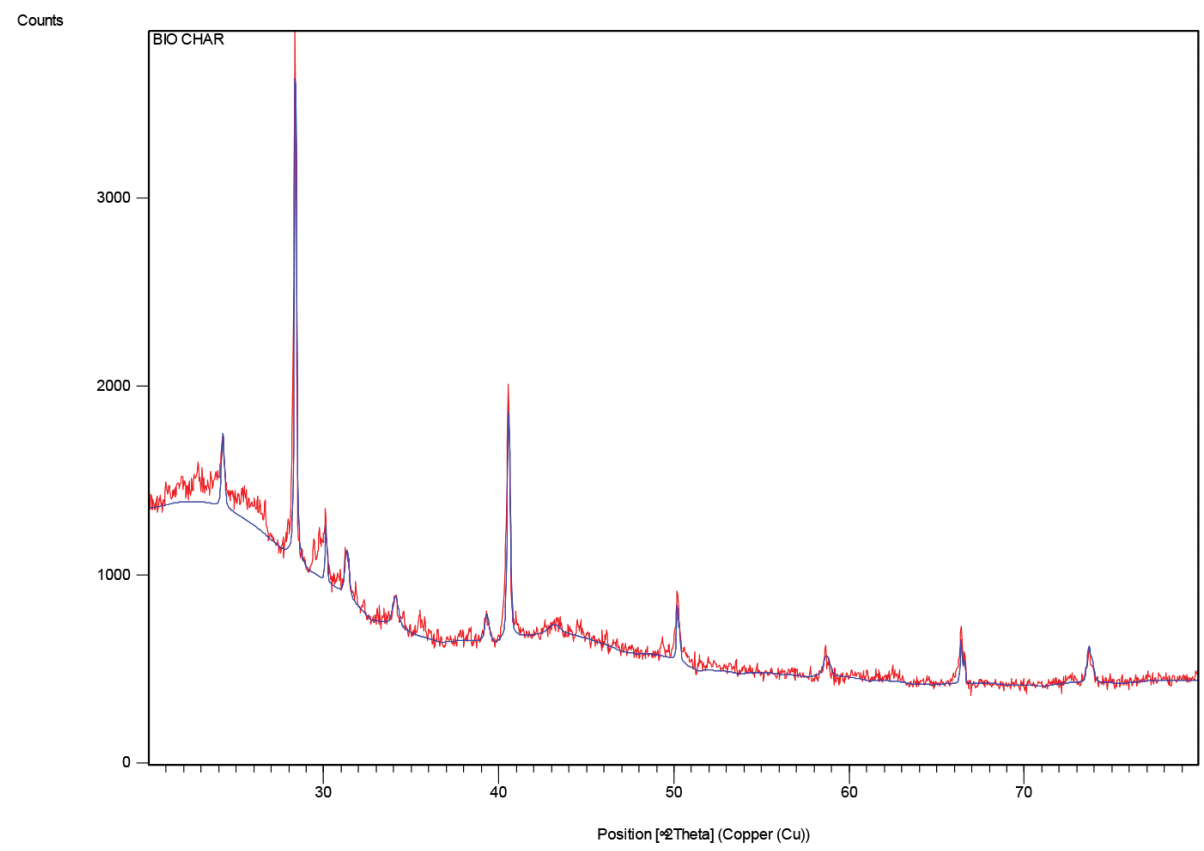

FIGURE 4. XRD spectrum of biochar 
TABLE 2. Properties of spent resins

\begin{tabular}{lc}
\hline \multicolumn{1}{c}{ Characteristics } & Spent Resins \\
\hline $\mathrm{pH}$ & $5.81 \pm 0.1$ \\
\hline Water content $(\%)$ & 38.33 \\
\hline Conductivity $(\mu \mathrm{S})$ & 24.6 \\
\hline Radionuclides content $(B q / g)$ & \\
Mn-54 & $133.26 \pm 2.30$ \\
Co-60 & $151.64 \pm 2.08$ \\
Zn-65 & $37.03 \pm 0.81$ \\
Cs-134 & $1.55 \pm 0.028$ \\
Cs-137 & $0.12 \pm 0.02$ \\
Eu-152 & $0.79 \pm 0.014$ \\
\hline
\end{tabular}

1985). A total of 64 formulations were conducted during this study. However, only 31 of the specimen blocks were acceptable to undergo the compressive strength test and 33 formulations failed to produce a free standing monolithic form due to either lack or excess of water. Table 3 gives the compressive strength of all the specimens tested after 28 days of curing. Out of 31 specimens tested for the compressive strength test, only one specimen failed to meet the minimum criterion of compressive strength for cement waste form i.e. 3.45 MPa as recommended by the Us Nuclear Regulatory Commission (NRC) Standard (NRC-US 1991). The results also showed that the compressive strength of cement-biochar-spent resins matrix was dependent on the initial water to cement ratio (w/c). A certain amount of water is required to achieve homogenous mixtures as cement will compete with spent resins for water during solidification process. Too little water, the mixture will not achieve sufficient fluidity for emplacement and compaction (Glasser 2011). At lower w/c (e.g. w/c=0.35), the mixtures exhibited very low workability and were difficult to prepare when the amount of spent resins increased. As the amount of spent resins and biochar increased, the water-to-cement ratio also increased. This indicates that more water is required to obtain a good workability and to produce a free-standing solid monolithic waste form.

TABLE 3. Compressive Strength (MPa) of specimens after 28 days

\begin{tabular}{|c|c|c|c|c|c|}
\hline $\begin{array}{l}\text { Water-to-cement } \\
\text { ratio }\end{array}$ & $\begin{array}{l}\text { Cement } \\
\text { wt }(\%)\end{array}$ & $\begin{array}{l}\text { Water } \\
\text { wt }(\%)\end{array}$ & $\begin{array}{l}\text { Biochar } \\
\text { wt }(\%)\end{array}$ & $\begin{array}{l}\text { Spent resin } \\
\text { wt }(\%)\end{array}$ & $\begin{array}{c}\text { Compressive strength } \\
(\mathrm{MPa})\end{array}$ \\
\hline \multirow[t]{2}{*}{0.35} & 71 & 25 & 2 & 2 & $21.51 \pm 1.44$ \\
\hline & 70 & 24 & 3 & 3 & $17.93 \pm 5.61$ \\
\hline \multirow[t]{4}{*}{0.40} & 69 & 28 & 2 & 2 & $22.29 \pm 1.74$ \\
\hline & 67 & 27 & 3 & 3 & $6.44 \pm 3.54$ \\
\hline & 65 & 26 & 4 & 4 & $4.60 \pm 1.05$ \\
\hline & 63 & 25 & 6 & 6 & $10.80 \pm 0.40$ \\
\hline \multirow[t]{3}{*}{0.45} & 69 & 30 & 1 & 1 & $15.51 \pm 2.44$ \\
\hline & 67 & 27 & 3 & 3 & $11.03 \pm 2.39$ \\
\hline & 61 & 31 & 4 & 4 & $5.10 \pm 1.70$ \\
\hline \multirow[t]{6}{*}{0.50} & 65 & 32 & 2 & 2 & $11.03 \pm 2.39$ \\
\hline & 72 & 24 & 2 & 2 & $14.25 \pm 1.44$ \\
\hline & 63 & 31 & 3 & 3 & $8.50 \pm 1.05$ \\
\hline & 61 & 31 & 4 & 4 & $11.72 \pm 1.83$ \\
\hline & 57 & 29 & 7 & 7 & $4.14 \pm 0.69$ \\
\hline & 48 & 30 & 11 & 11 & $8.50 \pm 1.05$ \\
\hline \multirow[t]{5}{*}{0.55} & 63 & 35 & 1 & 1 & $6.67 \pm 1.99$ \\
\hline & 61 & 33 & 3 & 3 & $6.21 \pm 1.19$ \\
\hline & 59 & 32 & 4 & 4 & $6.20 \pm 3.25$ \\
\hline & 54 & 35 & 5 & 5 & $4.83 \pm 3.0$ \\
\hline & 55 & 31 & 7 & 7 & $8.27 \pm 1.83$ \\
\hline \multirow[t]{4}{*}{0.60} & 61 & 37 & 1 & 1 & $9.42 \pm 1.05$ \\
\hline & 56 & 34 & 5 & 5 & $7.58 \pm 0.69$ \\
\hline & 54 & 32 & 7 & 7 & $8.27 \pm 1.83$ \\
\hline & 49 & 29 & 11 & 11 & $7.81 \pm 1.43$ \\
\hline \multirow[t]{3}{*}{0.65} & 56 & 36 & 4 & 4 & $8.50 \pm 1.05$ \\
\hline & 53 & 33 & 7 & 7 & $7.58 \pm 0.69$ \\
\hline & 48 & 32 & 10 & 10 & $7.12 \pm 1.05$ \\
\hline \multirow[t]{2}{*}{0.70} & 47 & 33 & 10 & 10 & $9.31 \pm 1.46$ \\
\hline & 42 & 30 & 14 & 14 & $5.97 \pm 1.06$ \\
\hline 0.75 & 41 & 31 & 14 & 14 & $5.52 \pm 1.20$ \\
\hline 0.90 & 33 & 35 & 16 & 16 & $3.22 \pm 0.80$ \\
\hline
\end{tabular}


TABLE 4. Compressive strength of selected cement-biochar-spent resins matrices after 14 days of immersion in distilled water and ground water

\begin{tabular}{cccccc}
\hline \multirow{2}{*}{$\begin{array}{c}\text { Water } \\
(\%)\end{array}$} & $\begin{array}{c}\text { Cement } \\
(\%)\end{array}$ & $\begin{array}{c}\text { Biochar } \\
(\%)\end{array}$ & $\begin{array}{c}\text { Spent Resins } \\
(\%)\end{array}$ & & \multicolumn{2}{c}{ Compressive strength (MPa) } \\
\cline { 5 - 6 } & & & & Immersed in distilled water & Immersed in ground water \\
\hline 31 & 61 & 2 & 2 & $16.55 \pm 3.70$ & $12.90 \pm 2.80$ \\
31 & 65 & 11 & 11 & $11.95 \pm 1.44$ & $12.41 \pm 2.95$ \\
29 & 48 & 3 & 3 & $12.87 \pm 4.30$ & $11.03 \pm 1.40$ \\
27 & 67 & 6 & 6 & $16.90 \pm 2.44$ & $15.52 \pm 0.50$ \\
25 & 63 & & & $13.80 \pm 3.50$ & $14.30 \pm 3.54$ \\
\hline
\end{tabular}

This shows that the spent resins and biochar content, water-to-cement ratio and the consistency of a resincement-biochar were interdependent. The compressive strength of cement-biochar-spent resins matrix tends to decrease with increase of spent resins loading. When the amount of spent resins increased to $16 \%$, it was observed that more water (i.e. $w / c=0.9$ ) was required to obtain the workable mixture. However, the specimen made with w/c $=0.9$ had a weak compressive strength (3.22 MPa) which was slightly lower than $3.45 \mathrm{MPa}$ as recommended by the US Nuclear Regulatory Commission (NRC) Standard. The weak compressive strength at higher $\mathrm{w} / \mathrm{c}$ is due to the larger pore present between the cement particles in the cement paste (Bentz 2008). At higher w/c a relatively higher degree of dilution of cement in the cement-water solution, may result in a lower rate of hydration and reduce heat of cement in early ages ( $\mathrm{Hu}$ et al. 2014). The compressive strength may be affected by the amount of biochar added to the formulation. Thus, further investigation should be conducted to study the effect of biochar contents on the compressive strength of cement-biochar-spent resins matrix.

\section{EFFECT OF WATER IMMERSION}

The immersion behavior of cemented radioactive waste is important to ultimately ensure the overall safety of a storage and disposal system (Saleh 2014). The visual observation on the specimens after a two week immersion test showed no cracks or swelling. The effect of water immersion type on the compressive strength values of cement-biocharspent resins are shown in Table 4 . The results show that the compressive strength of the specimens exhibited a slight increase when immersed in water. This may indicate that the further hydration occurred when the specimens were in contact with water. During the immersion test, some water may penetrate into the structural cemented waste interlayers, and lead to a decrease in the external porosity (Ouellet et al. 2007). Moreover, the dissolved silicates will precipitate and fill available spaces. When the voids are filled with precipitated phases, the material strength could be increased by refinement and segmentation of the porosity. Hence, this may contribute to increase in the compressive strength.

\section{CONCLUSION}

Based on this study, it was found that the water-to-cement ratio affected the compressive strength of cement-biocharspent resins matrix. However, it was clearly observed that the amount of spent resins added to the formulation leads to an increase in the water-to-cement ratio and hence influences the compressive strength of the cement-biocharspent resins matrix. The specimens that were subjected to the immersion test successfully passed the two weeks water immersion test without any cracks or swelling. Besides, the compressive strength of the specimens increased after the two weeks in water immersion test. Therefore, further work is needed to study the effect of biochar content on the compressive strength of the cement-biochar-spent resins matrix.

\section{ACKNOWLEDGEMENTS}

The authors would like to thank the Ministry of Science, Technology \& Innovation, (MOSTI) for the financial funding under the Sciencefund program (Project No. 03-03-01SF0135) and Nuclear Malaysia for providing laboratory facilities for this work.

\section{REFERENCES}

ASTM Standards C39/C39M-09a. 2010. Standard Test Method for Compressive Strength of Cylindrical Concrete Specimens ASTM International, West Conshohocken, United States.

Atkins, M. \& Glasser, F.P. 1992. Application of Portland cementbased materials to radioactive waste immobilization. Waste Management 12: 105-131.

Bentz, D.P. 2008. A review of early-age properties of cementbased materials. Cement \& Concrete Research 38: 196-204.

Chen, C., Chen, G., Chen, L., Chen, Y., Lehmann, J. \& McBride, B. 2011. Adsorption of copper and zinc by biochars produced from pyrolysis of hardwood and corn straw in aqueous solution. Bioresource Technology 102(19): 8877-8884.

Chun, Y., Sheng, G.Y., Chiou, C.T. \& Xing, B.S. 2004. Composition and sorptive properties of crop residue-derived char. Environ. Sci. Technol. 38: 4649-4655.

Glasser, F.P. 2011. Application of inorganic cements to the conditioning and immobilization of radioactive waste. In Handbook of Advanced Radioactive Waste Conditioning Technologies, edited by Ojovon, M. UK: Woodhead Publishing Limited. pp. 62-134. 
Hu, J.,Zhi, G. \& Kejin, W. 2014. Influence of cement fineness and water-to-cement ratio on mortar early-age heat of hydration and set times. Construction and Building Materials 50: 657-663.

IAEA. 1985. Treatment of Spent Ion-Exchange Resins for Storage and Disposal, Tech. Rep. Series No. 254, Vienna, Austria.

IAEA. 1993. Treatment and Conditioning of Spent Ion Exchange Resins from Research Reactor, Precipitation Sludges and Other Radioactive Concentrates. IAEA-TECDOC-689. Vienna, Austria.

IAEA, 2002. Treatment of Spent Ion-Exchange Resins for Storage and Disposal. Tech, Rep. Series No. 254, Vienna, Austria.

Junfeng, L. \& Jianlong, W. 2006. Advances in cement solidification technology for waste radioactive ion exchange resins: A review. Journal of Harzardous Materials 135(1-3): 443-448.

Lee, D.J. \& Wilding, C.R. 1989. Waste form properties. Proceedings of the Waste Management Symposia. pp. 319325.

NRC-U.S. Nuclear Regulatory Commission. 1991. Waste Form Technical Position. Revision 1. U.S. Nuclear Regulatory Commission, Washington, D.C.

Ojovon, M., Varlackova, G.A., Golubeva, G.A. \& Burlaka, O.N. 2011. Long-term field and laboratory leaching tests of cemented radioactive wastes. Journal of Hazardous Materials 187: 296-302.

Ouellet, S., Bussière, B., Aubertin, M. \& Benzaazoua, M. 2007. Microstructural evolution of cemented paste backfill: Mercury intrusion porosimetry test results. Cem.Concr.Res. 37(12): 1654-1665.

Saleh, H.M. 2014. Stability of cemented dried water hyacinth used for biosorption of radionuclides under various circumstances. Journal of Nuclear Materials 446: 124-133.
Sun, Q., Li, J. \& Wang, J. 2011. Solidification of borate radioactive resins using sulfoaluminate cement blending with zeolite. Nuclear Engineering and Design 241: 5308-5315.

Tavcar, P., Smodis, B. \& Benedik, L. 2007. Radiological characterization of low-and intermediate-level radioactive wastes. Journal of Radioanalytical \& Nuclear Chemistry 273(3): 593-596.

Tong, X.J., Li, J.Y. \& Xu, R.K. 2011. Adsorption of $\mathrm{Cu}$ (II) by biochars generated from three crop straws. Chemical Engineering 172(2-3): 828-834.

Zalina Laili* \& Muhamad Samudi Yasir

Nuclear Science Programme

School of Applied Physics, Faculty of Science \& Technology

Universiti Kebangsaan Malaysia

43600 UKM Bangi, Selangor Darul Ehsan

Malaysia

Mohd Abdul Wahab Yusof

Malaysian Nuclear Agency, Bangi

43000 Kajang, Selangor Darul Ehsan

Malaysia

*Corresponding author; email: liena@nuclearmalaysia.gov.my

Received: 7 August 2014

Accepted: 23 April 2017 